Article

\title{
Energy Poverty in Ecuador
}

\author{
Quishpe Sinailin Pablo ${ }^{1}$, Taltavull de La Paz Paloma ${ }^{2, * \mathbb{C}}$ and Juárez Tárraga Francisco ${ }^{2}$ \\ 1 Faculty of Economics, Central University of Ecuador; 170401 Quito, Ecuador; pdquishpe@uce.edu.ec \\ 2 Department of Applied Economics, University of Alicante, 03080 Alicante, Spain; Fjuarez@ua.es \\ * Correspondence: paloma@ua.es; Tel.: +34-956909693
}

Received: 27 September 2019; Accepted: 7 November 2019; Published: 11 November 2019

\begin{abstract}
This paper aims to identify the presence of energy poverty in Ecuador. Three indicators proposed by the European Union Energy Poverty Observatory (EPOV) are used to construct a multidimensional energy poverty index (MEPI) based on measure conditions associated with energy poverty, in areas related to delays in the payment of electricity bills, disproportionate expenses, hidden energy poverty, and the 10\% Boardman (1991) rule. The information comes from the Ecuatorian Life Conditions Survey. The results show that energy poverty is present in Ecuadorian households, at the national level, and just as these indicators have restrictions, advantages and disadvantages, which demand decisions about the choice of their use.
\end{abstract}

Keywords: Poverty measurement; Poverty analysis; Household analysis; Energy poverty; Ecuador

\section{Introduction}

"The link between energy and poverty begins to gain importance, as a line of research in the Social Sciences and as a thematic axis in the national development plans and instruments of Latin American countries" [1]. In this context, the economic inability of households to pay for energy is a real phenomenon that affects the quality of life of the population and has economic, social and environmental implications.

In this research, the presence of energy poverty in Ecuador is tested, and international well-accepted methods are proposed to identify it. For this purpose: First, three indicators proposed by the European Union Energy Poverty Observatory (EPOV: available at https://www.energypoverty.eu) that seek to measure conditions associated with energy poverty are used, in areas such as delays in the payment of electricity bills, disproportionate expenditure and, hidden energy poverty. Second, the $10 \%$ indicator proposed by Boardman [2] used for energy poverty measurement in several countries of the United Kingdom (UK). Besides, this paper proposes a multidimensional energy poverty index that aggregates these indicators.

The information on energy poverty in Ecuador is scarce or non-existent, which impedes the identification of the scope of this problem. Besides, there are no studies for most of the Latin-American countries developing an evaluation of energy poverty in regions with very different climatic areas. The originality of this paper falls into three domains. Firstly, it applies well-recognized measures, although new for Ecuador, to different regions in a developing country, reaching empirical evidence of that energy-poverty is present, including in areas with good temperatures. The second is to use the Life Conditions Survey to analyse fuel poverty but by constructing new variables using the existing data for the index calculation. The third is to build an index which could serve to monitor this problem in Ecuador, giving a relevant tool for policy-taken decisions.

The paper contributes to the state of knowledge by generating information on households living in conditions of energy poverty, its reasons and its severity, giving empirical evidence that supports the implementation of public policies and the existing academic discussion. 
The question that guided this research was: Is there an energy poverty problem in Ecuador, which requires particular strategies or is simply a manifestation of the low level of household income?

This paper is organised as follows. Section 2 contains Materials and Methods with points devoted to definitions, Measurement of energy poverty, Situation of the Energy sector in Ecuador, Methodology and Data Resources. Section 3 includes Results and Discussion, with two sections, one devoted to the calculation of the four indicators of energy poverty, and the proposed Multidimensional Energy Poverty Index (MEPI). Section 4 summarises and makes policy proposals.

\section{Materials and Methods}

\subsection{Definitions}

Energy poverty is probably as old as the human race itself, however, as a concept it is a more recent fact, was recognized as a problem in the 1970s, after the 1973-1974 oil crisis and the decision of the UK government to gradually eliminate subsidies to the electricity and gas industries [3].

For Meszerics [4], a high percentage of the research carried out on this topic coincides in that low income, low thermal efficiency in housing, and high energy costs, are three crucial factors in energy poverty.

The first definitions of energy poverty were posed by Isherwood and Hancock (1978) who "define households with high fuel expenditure as those that spend more than twice the median on fuel, lighting, and energy". Moreover, Richardson (1984) "As the situation where people cannot access the source of energy (fuel) required for heating, lighting and cooking food" [5] (p. 368).

For Lewis [6] a household is in fuel poverty when it cannot afford the fuel necessary to maintain the heat or temperature that provides thermal comfort or household members, according to Garcia [1] (p. 14) Lewis makes a mere definition without a methodological approach that allows identifying when a household is in a situation of fuel poverty. Boardman [2] (p.219) defines it as "the inability to provide adequate heat due to the inefficiency of the household", sets a threshold of energy expenditure of $10 \%$ of household income, to identify whether or not a household is in fuel poverty.

For García [1], there is a semantic discussion in the studies of energy and poverty in the sense that, in the UK, the term fuel poverty is used, however, as this research expands to other countries such as France, Germany, Italy, Poland, the term energy poverty is used more frequently.

The definition and measurement are not homogeneous in the European Union (EU) countries, in a research carried out by Unit National Development Programme-UNDP [7] (pp.101-104). For Chile a table is presented that summarizes the main definitions, the operationalization or metrics used and the state of institutional formalization of energy poverty or fuel poverty of Australia, Belgium, Cyprus, France, Ireland, Italy, Malta, Slovakia, UK (England, Scotland, Wales, Northern Ireland) (see Table 1 from Pye [8], pp. 34-36 and 43 in case of Belgium).

Regarding Latin America, there is no formal definition of energy poverty, its research is still incipient, but with a growing interest in the subject, there are several academic and institutional works (ECLAC; World Bank, OLADE) developed in Brazil, Peru, Dominican Republic, Venezuela, Guatemala, Argentina, Chile, Mexico [7].

However, Garcia [1], proposes the following definition "A household is in energy poverty when the people who live there do not meet the needs of energy, which are related to a series of satisfiers and economic goods that are considered essential, in a specific place and time, according to social and cultural conventions". 
Table 1. Member State of the EU definitions of energy poverty.

\begin{tabular}{|c|c|}
\hline $\begin{array}{l}\text { Member States } \\
\text { of the EU }\end{array}$ & Definition, Metric and Status \\
\hline Australia & $\begin{array}{l}\text { Defines it as "households whose incomes are below the poverty risk threshold, and } \\
\text { simultaneously have to spend a percentage higher than an average of their household } \\
\text { income on energy" for their measurement proposes the use of family income indicators, } \\
\text { housing expenditure, energy costs. }\end{array}$ \\
\hline Belgium & $\begin{array}{l}\text { Makes a distinction between energy poverty and hidden energy poverty, it defines the } \\
\text { former as "households that spend too high a proportion of their disposable income on } \\
\text { energy" and the latter as "households that have an abnormally low level of expenditure on } \\
\text { the service of energy", the expenditure threshold is equivalent to twice the average of the } \\
\text { relationship between energy expenditure and household income. The latter occurs when } \\
\text { the household expenditure is below than half of the household expenditure of households } \\
\text { of the same size and type }\end{array}$ \\
\hline Cyprus & $\begin{array}{l}\text { Relates energy poverty to the situation of customers who may be in a position to define it } \\
\text { as challenging because of the low income that does not allow them to cover basic electricity } \\
\text { supply needs; the measure refers to the percentage of income spent on energy }\end{array}$ \\
\hline France & $\begin{array}{l}\text { Considers in a situation of energy poverty "a person who finds in his home particular } \\
\text { difficulties in having sufficient energy supply to meet basic needs due to low levels of } \\
\text { income or housing conditions". To this end, the country proposes three not operationalised } \\
\text { indicators. Firstly, a measure calculated as the rate of energy effort (ratio between energy } \\
\text { expenditure and household income) which should not exceed } 10 \% \text { considered only for the } \\
\text { first three deciles of income. The second indicator of low income-high expenditure means } \\
\text { that a household is in energy poverty if flow income and high energy expenditure meet } \\
\text { simultaneously. Third, a cold indicator, which is measured based on testimonies about the } \\
\text { level of thermal comfort }\end{array}$ \\
\hline Ireland & $\begin{array}{l}\text { Energy poverty "is a situation in which a household cannot reach an acceptable level of } \\
\text { domestic energy services due to affordability costs". This country applies three thresholds } \\
\text { to identify the severity of energy-poor: The first } 10 \% \text { of the disposable income expenditure } \\
\text { in energy bill; the second level is when the expenditure uses the } 15 \% \text { and the third } 20 \% \text {; the } \\
\text { latter two categories being used to measure severe and extreme energy poverty }\end{array}$ \\
\hline Italy & $\begin{array}{l}\text { A family is energy vulnerable when it spends more than } 5 \% \text { of its income on electricity and } \\
\text { more than } 10 \% \text { on gas. }\end{array}$ \\
\hline Malta & $\begin{array}{l}\text { does not have a definition official, but, if there is a definition made by NGOs, which relates } \\
\text { energy poverty to the inability to reach the level of fuel use needed to heat the housing }\end{array}$ \\
\hline Slovakia & $\begin{array}{l}\text { Energy poverty "is a state in which the average monthly expenditure of households on the } \\
\text { consumption of electricity, gas, heating and domestic hot water represents a substantial } \\
\text { part of the average monthly income of the household". A household can be considered as } \\
\text { weak energy if the available monthly income is less than the minimum monthly threshold } \\
\text { available for family income; the threshold is published on the website of the Ministry } \\
\text { of Labor }\end{array}$ \\
\hline $\begin{array}{l}\text { The } \\
\text { UK-England }\end{array}$ & $\begin{array}{l}\text { Household is fuel poor "if income is below the poverty line, and if energy costs are higher } \\
\text { than typical for every type of household." They use the low-income indicator-high rates } \\
\text { (LIHC), which considers two criteria that must be met simultaneously, the first that the fuel } \\
\text { costs are above the median and the second that the disposable income minus the } \\
\text { expenditure on fuel is below the poverty line. Additionally, the 10\% Boardman rule } \\
\text { threshold measurement is also applied. }\end{array}$ \\
\hline $\begin{array}{l}\text { The } \\
\text { UK-Scotland }\end{array}$ & $\begin{array}{l}\text { Household is in fuel poverty "when to maintain an adequate heating regime the household } \\
\text { spends more than } 10 \% \text { of their income on fuel consumption". As an adequate heating } \\
\text { regime, the World Health Organization (WHO) recommendation stablishes } 23^{\circ} \mathrm{C} \text { in the } \\
\text { living room and } 18{ }^{\circ} \mathrm{C} \text { in other rooms for, at least, } 16 \mathrm{~h} \text { a day in rooms used by older adults, } \\
\text { handicapped people, or with chronic diseases and } 21^{\circ} \mathrm{C} \text { in the living room and } 18{ }^{\circ} \mathrm{C} \text { in } \\
\text { other rooms for a period of } 9 \mathrm{~h} \text { a day for other household types }\end{array}$ \\
\hline UK-Wales & $\begin{array}{l}\text { "When more than } 10 \% \text { of the income is spent on all types of domestic fuel to maintain an } \\
\text { adequate heating regime"; households are in a situation of severe energy poverty when } \\
\text { expenses exceed } 20 \% \text {. }\end{array}$ \\
\hline $\begin{array}{l}\text { UK-Northern } \\
\text { Ireland }\end{array}$ & $\begin{array}{l}\text { Households are in energy poverty when allocate more than } 10 \% \text { of its income in } \\
\text { consumption of domestic fuel to maintain an acceptable level of temperature throughout } \\
\text { the house. }\end{array}$ \\
\hline
\end{tabular}

Source: Pye, S and Dobbins, A, 2015, pp. 34-36, and 43 or PNUD 2018, pp. 101-104. 
According to Urquiza [9], the notion of energy poverty in Chile has been incorporated as an official development goal within the current long-term energy policy. However, the policies proposed still have a rather fragmented and sectorized character, which may be the result of an absence of adequate indicators. The indicators focus on measuring access to electricity service, leaving aside the questions of the quality standard, cultural and climatic differences that make the real manifestation of energy poverty vary between households. Some of the indicators used in the measurement of energy poverty in Chile are the 'Ten-percent-Boardman' rule, MIS-Based approaches and Low Income_High Cost, Multidimensional Energy Poverty Index, The Energy Supply Index, The Multi-Tier Framework for Measuring Energy Access.

\subsection{Measurement of Energy Poverty}

For Garcia [1] there are two approaches used to measure fuel poverty, subsistence and consensual. The first approach bases the estimation of a poverty line based on the temperature threshold necessary to achieve the thermal comfort that is considered adequate or a percentage of the household income destined to fuel expenditure. Within this approach would be studies developed by authors such as “Lewis (1992), Boardman (1991), Whyley and Callender (1997), Clinch and Healy (1999, 2001), Healy y Clinch (2002a, 2002b and 2003)" Garcia [1] (p.14)

The second focuses the theory of "relative deprivation" developed by Peter Townsend in the construction of a synthetic index of relative deprivation. The index is composed of three objective indicators (it has heating equipment, thermal insulation and hermetic windows) and three personal ones (people's satisfaction in need of heating, ability to pay the energy bill and if they think the facilities are adequate). Within this approach, we would have authors such as Healy (2004), SEI (2003), Harris (2005), Tirado and Unge-Vorsatz (2010), Finsh (2010), Buzar (2007 and 2007b). Garcia [1].

Thomson [10], mentions that there are three methods to measure energy poverty: The expenditure approach, consensual and direct measurement, the Consensus approach and the Direct measurement.

The "expenditure approach analyses the energy expenditure that households have about an absolute or relative threshold to estimate the extent of domestic energy deprivation. The Consensus approach based on self-reported assessments of housing conditions inside the household and the ability to meet certain basic needs with the society in which they reside. The Direct approach measures whether the level of energy services (such as heating) achieved in the household meets a relative acceptable value compared to an established standard" [10] (p.883).

Tirado [11] (p. 26), mentions that it is possible to talk about three typologies of thresholds for the household expenditure and income approach. "First, excessive energy expenditures, either measured in absolute or relative terms (as a percentage of annual income). Second residual income below a line of monetary poverty after discounting expenditures on housing and energy. Third, the level of expenditure is too low (only when the starting data refer to actual and not theoretical expenses necessary)". Additionally, it is worthy of mentioning that in many cases, temperature ranges inside the houses have been used as thresholds.

With the new directive of the internal electricity market-the common EU electricity market obliges for the first time the Member States to have their mechanisms to measure energy poverty, in this sense the EPOV was launched in 2016, who should propose pan-European indicators that allow obtaining methodologically consistent results [11].

The EPOV [11] proposes two types of indicators: primary and secondary. First, the mains that can be calculated by all the Member States, based on microdata from the Family Budget Survey (FBS) and the Living Conditions Survey (LCS), these are four: Percentage of the population who declared themselves unable to maintain their housing at an adequate temperature. Percentage of population that declares delays in the payment of housing bills. Disproportionate expenditures that measure the percentage of the population for which actual household energy expenditures (as a percentage of total household income) is twice above the median. Hidden energy poverty measures the percentage of the population for which the expenditure on domestic energy is below half of the national median. 
Second, the secondary indicators that consider causal factors such as energy prices, data on energy labelling of buildings, energy costs per income quintile, among others. And complementary aspects such as housing with a comfortable temperature in summer and winter, presence of leaks, humidity or $\operatorname{rot}[11]$ (p. 32).

The results of several of these indicators available for Spain show that 4.6 million people were unable to maintain their home at an adequate temperature, 3.6 million people did not pay the energy bills in the established time, $2 \%$ of residents lacked in energy supply in 2016. This result places Spain in an intermediate position among the EU member countries, however, it triples the energy poverty rates of the countries of northern and western Europe as the Netherlands, Sweden, Denmark, and are far from the incidence rates of 20,30 and up to $40 \%$ present in the countries of southern and eastern Europe such as Greece, Bulgaria, Lithuania, Croatia, Romania, Portugal [11].

Mendoza [12] propose the Compound Energy Poverty Indicator (CEPI) to analyse energy poverty in the Canary Islands-Spain in the years 2006-2016, this indicator is the result of a combination of three indicators, the $10 \%$ rule, Low Income/High Cost (LIHC) and After Fuel Cost Poverty (AFCP). As a result of the application, it found that $11.4 \%$ of households in the Canary Islands in 2016 experienced energy poverty.

Maxim [13] proposes the Compound Energy Poverty Indicator (CEPI) forecasting model, which uses a multiple linear regression to establish to what extent and how energy poverty can be explained and determined, as dependent variables of the model considers: People at Risk of Poverty or Social Exclusion, Affordability of Energy and Heating System Efficiency — applied to 28 member states of the European Union.

Garcia [1] proposes the method of Satisfaction of Absolute Energy Needs as a conceptual and methodological framework to address energy poverty in Latin America. This proposal approaches the Unsatisfied Basic Needs Method that is used by ECLAC to measure poverty. With this, it builds a Household Energy Poverty Index (HEPI). Used this index for Mexico and find that it is a phenomenon present in urban and rural areas. Energy poverty is in absolute terms higher in urban than in rural areas; the data shows that 7.8 million urban households with 4.5 million rural households experienced this type of poverty.

Kozulj [14], finds that energy poverty is different in rural areas and urban areas in Latin America and the Caribbean. The type of deprivation that occurs due to the absence of monetary income and access to essential public services, including energy, is different. As a consequence of the geographical, cultural, climatic diversity and inequality that is not only manifested through access to the different services, their relative cost and the more significant proportions of family income to meet energy needs, but it is also evident through access to household equipment and communities, which in turn reflects in the level of energy consumption.

He found that the weak strata consume 8 times less the amount of energy than the rest of the social strata, but allocate a more significant proportion of their income to the payment of energy in relation to the non-poor, the energy-income difference would be up to 13 times when analyzing the households in the lower $20 \%$ of the income distribution in relation to the wealthiest $20 \%$.

"The scarce and dissimilar information exists reveals that, in Latin America and the Caribbean, the absence of electrical services is related to poverty, although in some cases it can also respond to geographic isolation or other barriers to access. However, in $73 \%$ of the cases of poor households, that lack of electricity is the main cause (suggesting that in that type of region) a little more than $10 \%$ of the poor or, about $30 \%$ of the homeless, lack electrical services" [14] (p.13).

In addition to these indicators used in the measurement of energy poverty, it is worth mentioning that there are others such as Energy Development Index (EDI) proposed by the International Energy Agency (IEA), which measures progress in the transition to more modern and efficient fuels and services. Multidimensional Energy Poverty Index (MEPI) proposed by Nusbaumer, Bazilian, Modi in 2012 [15] and Nusbaumer, Bazilian, Modi and Yumkella in 2011 [16], this indicator is the product of an incidence rate (percentage of people identified as energy poor) times the intensity of deprivation of 
the energy poor, classified in levels from moderate to severe. Multi-Tier Framework (MTF) proposed by the World Bank. Energy Poverty Index (EPI) proposed by Mirza and Szirmai in 2010 [17] and calculated in Nussbaumer et al. in 2013 [18], Fabbri (2015) for Italy [19] and Okushima (2017) for the case of Japan [20].

The bibliographic review shows that there is no exclusive and consensual definition of energy poverty and its form of measurement. The definitions vary according to the authors and the countries, which implies a challenge in the measurement, setting of standards, minimum thresholds and baselines, as well as the statistical systems necessary to size them.

However, as it can be seen in the literature, there is not a common method or procedure to measure energy poverty. The heterogeneity comes from limitations in the availability of data as well as the use of information coming from other's purposes diversified sources (surveys) or instruments for collecting information, such as the National Socio-Economic Characterization Survey (CASEN) in Chile, Households Budget Survey in Mexico, the National Household Income and Expenditure Survey (ENICH) in Spain, the Household Budget Survey (EPF) and the Living Conditions Surveys $(\mathrm{ECV})$, which provide information on income, education, health, living conditions and housing. Although these surveys are representative at the national level, the information on energy expenditures provided is not sufficiently detailed, obliging the researcher to model the information, resulting in the non-comparability of results between countries and in many cases proposing a new measurement methodology for energy poverty. This paper used a combined methodology to approach the energy poverty in Ecuador and add additional evidence to the literature about how a Multidimensional index could serve as a common method to follow this phenomenon.

The following sections present a description of the energy sector in Ecuador.

\subsection{The Situation of the Energy Sector in Ecuador}

According to the National Energy Balance [21] (the base year 2016), primary energy production reached 229.4 thousand barrels of oil equivalent (BOE or Kbep), exporting $61 \%$. The main sources of primary production are fossil energy that together (oil $87.6 \%$ and natural gas $4.6 \%$ ) represent $92.2 \%$, and renewable energy with $7.8 \%$ (hydropower $5.3 \%$, firewood, products of cane, wind, solar, pine nut oil and urban solid waste).

In 2016 [21,22], the main consumption sectors identified were: transport sector $48.8 \%$ of total national energy consumption, industrial sector $(15.7 \%)$, residential sector $(13.3 \%)$, Commercial sector $(6.3 \%)$, agro-fishing and mining $(1 \%)$ and others $(1 \%)$, the self-consumption of the energy sector represents $4.5 \%$. The main energy consumed in the different sectors were diesel, gasoline and naphtha, electricity, liquefied petroleum gas and fuel oil.

According to the Electricity Regulation and Control Agency [23], per capita consumption ( $\mathrm{kWh} / \mathrm{hab})$ in 2007 was 705.12, and in 2017, it was 1157.99 . The energy service coverage reached $97.1 \%$ in 2016 .

As the research seeks to measure energy poverty, information on energy consumption in the residential sector appears below. As can be seen in Table 2, the sources of energy consumed come from primary and secondary production. In 2016, this sector required $12.083 \mathrm{Kbep}$, representing $13.32 \%$ of national consumption. Liquefied petroleum gas represents $51.24 \%$ of the total energy consumed by this sector, followed by electricity with $36,43 \%$, firewood with $12.3 \%$ and the remaining $0.03 \%$ corresponds to other energy sources. 
Table 2. Energy consumption residential sector 2007-2016.

\begin{tabular}{|c|c|c|c|c|c|c|c|c|c|c|}
\hline \multicolumn{11}{|c|}{ Energy Consumption by the Residential Sector (Kbep) } \\
\hline Consumption & 2007 & 2008 & 2009 & 2010 & 2011 & 2012 & 2013 & 2014 & 2015 & 2016 \\
\hline Natural Gas & - & - & - & - & - & - & 0.5 & 0.5 & 2.2 & 3.3 \\
\hline Firewood & 2.249 & 2.163 & 2.053 & 1.956 & 1.914 & 1.804 & 1.718 & 1.695 & 1.534 & 1.486 \\
\hline Primary Total & 2.249 & 2.163 & 2.053 & 1.956 & 1.914 & 1.804 & 1.719 & 1.696 & 1.536 & 1.489 \\
\hline Electricity & 2.537 & 2.717 & 2.895 & 3.169 & 3.315 & 3.488 & 3.644 & 3.943 & 4.292 & 4.402 \\
\hline Liquified gas & 4.906 & 5.097 & 5.294 & 5.476 & 5.681 & 5.878 & 6.078 & 6.287 & 6.294 & 6.191 \\
\hline Kerosene/Jet fuel & 3.1 & 2.2 & 1.6 & 1.2 & 0.7 & 0.5 & 0.4 & 0.3 & 0.2 & 0.2 \\
\hline Secondary Total & 7.446 & 7.816 & 8.191 & 8.646 & 8.997 & 9.367 & 9.722 & 10.230 & 10.586 & 10.593 \\
\hline Final Consumption & 9.695 & 9.979 & 10.244 & 10.602 & 10.911 & 11.171 & 11.441 & 11.926 & 12.122 & 12.083 \\
\hline \multicolumn{11}{|c|}{ Energy Consumption by the Residential Sector in Physical Units } \\
\hline Consumption & 2007 & 2008 & 2009 & 2010 & 2011 & 2012 & 2013 & 2014 & 2015 & 2016 \\
\hline Natural Gas by MMPC & - & - & - & - & - & - & 3 & 3 & 13 & 20 \\
\hline Firewood by Kton & 867 & 834 & 792 & 754 & 738 & 696 & 662 & 653 & 591 & 573 \\
\hline Electricity by GWH & 4.095 & 4.385 & 4.672 & 5.114 & 5.351 & 5.629 & 5.881 & 6.364 & 6.928 & 7.105 \\
\hline Liquified gas thousands of $\mathrm{Kg}$ & 643.005 & 668.070 & 693.896 & 717.650 & 744.579 & 770.340 & 796.644 & 823.955 & 824.899 & 811.388 \\
\hline $\begin{array}{l}\text { Kerosene/Jet fuel thousands } \\
\text { of gallons }\end{array}$ & 135 & 98 & 71 & 53 & 32 & 22 & 16 & 12 & 9 & 7 \\
\hline
\end{tabular}

Source National Energy Balance 2017, p. 68.

\subsection{Methodology}

For the measurement of energy poverty, the application of indicators based on the expenditure and income approach is proposed:

First, the $10 \%$ indicator originally proposed by Boardman [2] calculated as:

$$
\mathbf{H}^{* *} \geq \mathbf{H}=\frac{\text { Energy expenditure }}{\text { household disposable income }}
$$

where:

$\mathrm{H}=$ percentage of disposable income destined to the payment of energy

$\mathrm{H}^{* *}=$ Standard percentage for energy expenditure ( $10 \%$ of the equivalent income)

Condition:

- If $\mathrm{H}>=\mathrm{H}^{* *}$ the household falls into energy poverty.

- If $\mathrm{H}<\mathrm{H}^{* *}$ the household does not fall into energy poverty.

Second, three of the four leading indicators proposed by the EPOV 2018, which are [11]:

- Delays in the payment of electricity bills, calculated as:

$$
\mathbf{R}=\frac{\text { Number of households with delayed electricity bills }}{\text { Total number of households with electricity service }}
$$

where:

$\mathrm{R}=$ percentage of households with delays in the payment of electricity bills in the reference period.

- Disproportionate expenditures [11]: which measures the percentage of households for which the actual expenditures on domestic energy (as a percentage of disposable household income) is twice above the median. That is, in Ecuador, the median energy expenditure per household is $2.19 \%$ of its income; those households that allocate more than $4.37 \%$ of their annual income to energy payments will be counted. 
- Hidden energy poverty [11]: which measures the percentage of households for which the total expenditure on domestic energy is below half of the national median. That is, if the median energy expenditure of the country is 156 dollars per household and year, those include all households whose energy expenditure is less than 78 dollars per household and year.

"The indicators based on expenses and income normally allow considering all energy services to the extent that they are reflected in the household budget" [11] (p.27). In this sense, for the calculation of the expenditure on domestic energy in Ecuador, expenditure is added together the following variables: electricity, domestic gas for cooking and other uses, coal, candles of any kind and fuel not destined for a vehicle such as gasoline, diesel or Kerex of each household surveyed, when the indicated one so requires.

For the calculation of disposable income, the sources of monetary income of households from salaried employment, independent employment and income from other activities and income deductions such as direct income taxes, mandatory and voluntary contributions to security are considered, social, and contributions to associations-judicial retentions.

In the identification of households with delays in the payment of electric bills, the housing database in the ECV, precise questions, was used: VI28-Do you pay for electricity? Which has three possible answers (Yes, Yes with the rent, and No); the households that answered yes, if they also say to be in rent, are selected. VI28A Value paid for electricity; in this case, the coding "does not inform" or "did not pay last month" is considered household with delays payment. When the answer to question VI28A is yes, it is considered a payment for electricity. The question VI28B gives the number of months paid for electricity; in that case, the codification system proceeds in the same way as in VI28A regarding the coding "does not inform" and "did not pay last month, as households with delays of payment".

When the answer was "yes with the rent", the identification of whether or not the household has delayed the energy payment is evaluated taking into account the answer given to question VI37 (Did they pay last month for renting this house?). When the answer is no, the household has delays in the payment of the electricity service; the opposite happens when the answer was yes.

\section{Multidimensional Index Methodology}

The multidimensional energy poverty index (MEPI) identifies multiple conditions associated with energy poverty experienced by a household in terms of disposable income, expenditure on energy (electricity, domestic gas for cooking and other uses, coal, candles of any kind and fuels not intended for a vehicle such as gasoline, diesel or Kerex), delays in the payment of electricity bills. This index uses microdata from LCS. The index construction follows the Alkire-Foster [24-26] methodology proposed for the calculation of the multidimensional poverty index but adapting it to three indicators established by the EPOV (2018) [11] and an indicator proposed by Boardman to measure energy poverty, which imposes specific guidelines that the index must follow.

The MEPI is a limited index between 0 and 1 where one means that all households are energy poor in the four selected indicators and 0 in case no household is multidimensional energy poor.

The multidimensional energy poverty index is estimated as the product of two measures. The first is the incidence ratio (EPIR), which indicates how many households are multidimensional energy poor. The second is the intensity ratio (IEP) that allows knowing the average of the conditions associated with the energy poverty presented by these households. The Multidimensional Energy Poverty Index (MEPI), then, is a measure that summarises the incidence and intensity of energy poverty. The calculation of each of these measures is detailed below.

The synthetic measure is the multidimensional energy poverty index, calculated as the product of the incidence by intensity. The formula is as follows:

$$
\text { MEPI }=\text { EPIR * IEP }
$$

where: 
MEPI $=$ Multidimensional energy poverty index

EPIR $=$ Energy poverty incidence rate

IEP = Intensity of energy poverty among the energy-poor

The energy poverty incidence rate is a percentage of households that are in energy poverty times the total number of households in the country. The incidence formula is as follows:

$$
\operatorname{EPIR}=\frac{\mathbf{q}}{\mathbf{n}}
$$

where $\mathbf{q}$ is the number of households identified as energy poor (according to the score associated with energy poverty $>0.25$ ), and $\mathbf{n}$ is the total households.

The calculated measure does not allow to know how poor these households are from the energy perspective, or in which indicators these households are energy-poor. Therefore, although the incidence ratio would decrease, the final multidimensional index would remain in the former values, or even it may increase.

The intensity of energy poverty makes it possible to determine the total number of households under energy poverty and the conditions determining the reasons for energy poor. The formula for intensity is as follows:

$$
\text { IEP }=\frac{\sum_{1}^{\mathbf{q}} \mathbf{q}_{\mathbf{i}} * \mathbf{c}_{\mathbf{i}}}{\sum_{1}^{\mathbf{q}} \mathbf{q}_{\mathbf{i}} * \mathbf{k}}
$$

where: $q_{i}$ is the household identified as energy-poor according to the number of conditions associated with energy poverty that are presented (in this paper 2,3 or 4 ), $\mathbf{c}_{\mathbf{i}}$ is the sum of the scores associated with energy poverty calculated for the household identified in energy poverty, and $\mathbf{k}$ represents the number of indicators (in this paper 4).

\subsection{Data Resources}

The source is a set of cross-sectional data for the year 2014 from the Living Conditions Survey of Ecuador (LCS) $[27,28]$. This survey provides annual data on income, expenditures, socio-demographic characteristics of a theoretical sample of 29.870 , of which $1.8 \%$ are missing data in the system for households that were not able to calculate disposable income due to lack of information, and $2.9 \%$ are missing data for households that were not able to calculate energy expenditure. The missing data will make the cases valid for analysis differ when information from one or a combination of variables must be applied.

Consumption and income aggregate databases are constructed to obtain the variables of electricity expenditure, fuel expenditure and disposable income per household. The methodological guidelines proposed by the National Statistics and Census Institute of Ecuador (INEC) [29-31], the Economic Commission for Latin America and the Caribbean (ECLAC) [32], the World Bank (WB), the International Labor Organization (ILO) [33] and the final report of the Canberra Group on statistics relating to household income (CG) [34], all them are followed to build the database.

Descriptive statistics of variables from 2014 are in Table 3; there is a large gap between the mean values of the input-output variables and the maximum values (or the minimum values), which means that there are significant differences in the inputs and outputs across Ecuador provinces. 
Table 3. The statistical description of input-output variables for 2014.

\begin{tabular}{cccc}
\hline \multirow{2}{*}{ Year } & Statistics & Expenditure & Disposable Income \\
\hline \multirow{2}{*}{2014} & Median & 156.00 & 7106.00 \\
\cline { 2 - 4 } & Standard deviation & 184.08 & $15,710.90$ \\
\cline { 2 - 4 } & Maximum & 3.00 & -984.00 \\
\cline { 2 - 4 } & Minimum & 1872.00 & $453,772.96$ \\
\hline
\end{tabular}

Source Living Conditions Survey-Sixth Round, November 2013-October 2014 (INEC) Prepared by the authors.

\section{Results and Discussion}

\subsection{Results of the Four Indicators of Energy Poverty}

In this section presents the results of the four indicators, the analysis is carried out from a household income perspective, depending on the territorial scope and some socio-demographic characteristics.

The results of Table 4 provide evidence of the incidence of energy poverty in Ecuador. As is evident, the indicators are complementary to each other, measure different circumstances, experiences and ways to deal with energy vulnerability.

Table 4. Households experiencing conditions associated with energy poverty in Ecuador (2014).

\begin{tabular}{|c|c|c|c|}
\hline Indicators & Valid Cases & $\begin{array}{l}\text { Households in Conditions } \\
\text { Associated with Energy Poverty }\end{array}$ & $\begin{array}{l}\text { Energy Poverty } \\
\text { Rate }\end{array}$ \\
\hline $\begin{array}{l}\text { Delayed payment of } \\
\text { electricity bills }\end{array}$ & 3916.748 & 144.456 & $3.70 \%$ \\
\hline $\begin{array}{l}\text { Disproportionate energy } \\
\text { expenditure }\end{array}$ & 4134.611 & 969.011 & $23.40 \%$ \\
\hline $\begin{array}{l}\text { Hidden Energetic } \\
\text { Poverty }\end{array}$ & 4241.408 & 671.987 & $15.80 \%$ \\
\hline $\begin{array}{l}10 \% \text { indicator } \\
\text { (Boardman) }\end{array}$ & 4134.611 & 329.638 & $8 \%$ \\
\hline
\end{tabular}

Source Living Conditions Survey—Sixth Round, November 2013-October 2014 (INEC) Prepared by the authors.

Households that did not pay any of the receipts for electricity service on time represent $3.7 \%$ (144.456) of households nationwide in 2014, of which $75.9 \%$ (109.612) had two and three months late in the last twelve months.

The low percentage of unpaid invoices would be partly explained by the high economic charges associated to both the non-payment on the established deadline (interest for late payment, cost of collection management) which is followed by the suspension of the service, and the high percentage of households that pay its accounts on time (high collection rate of the electric companies). For example, the Electricity Quito Company that provides the electric service to the provinces of Pichincha and Napo presented an average level of collection for the sale of energy in 2014 of $99.21 \%$ [28].

Sanctions are based on the Organic Law of Public Energy Services [35-37] in force, in Article 71 "Suspension of services" literal 1, and in the Regulations to the Electricity Regime Law, in Article 17 "Coactive Jurisdiction."

In 2014, expenditures on domestic energy (electricity, domestic gas for cooking and other uses, coal, candles of any kind and fuel not destined for a vehicle such as gasoline, diesel or Kerex) for $23.4 \%$ (969.011) of Ecuadorian households they were disproportionately high in relation to their income and with respect to the national median of expenditure (that is, the percentage of income dedicated to paying for energy exceeded twice the national median). Besides, $15.8 \%$ (671.987) of households had unusually low energy expenditures (their household expenditure was below $50 \%$ of the annual median); this is so-called hidden energy poverty. The households that experienced both conditions 
were 19.719, that is to say, they had disproportionately high expenses (concerning income) when those expenses are at the same time unusually low compared to the national median of energy expenditure.

The 10\% indicator (Boardman's rule) shows that $8 \%$ of households would have experienced energy poverty in 2014.

The limitations in the information in the LCS in the "real energy expenditure" is relevant when interpreting the results. Lack of data may generate the number of households falling into conditions associated with energy poverty to be underestimated, as the value reported by families is the amount paid and not the actual value of consumption given the existence of subsidies (for instance cross-subsidy and dignity rates). Besides, households would reduce energy consumption to avoid high bills. This difference is fundamental when it comes to an understanding and comparing the results of the application of the indicators. This hypothesis would be part of future research.

The disaggregation of the indicators by region and urban, rural location shows that households in the Sierra and Amazon rural areas are more vulnerable to experiencing energy poverty than urban ones in the four indicators analysed. On the Coast, indicators of hidden energy poverty, disproportionate energy expenditures and delays in payment of receipts coincide in the fact that households located in the rural area experienced greater energy poverty. Among the rural areas categories in Table 5, the rural area of the Amazon is the one that shows in the Boardman indicators, disproportionate energy expenditures and delays the highest percentage of households in energy poverty, and households located in the rural Costa region for the hidden energy poverty indicator. Also, the indicators show that energy poverty is present in all regions and urban or rural areas and with it, the existence of a spatial dimension.

Table 5. Household experiencing conditions associated with energy poverty in Ecuador (2014).

\begin{tabular}{|c|c|c|c|c|c|c|c|c|}
\hline \multirow{3}{*}{$\begin{array}{l}\text { Region and } \\
\text { Location }\end{array}$} & \multicolumn{8}{|c|}{$\begin{array}{l}\text { Number of Households Experiencing Conditions Associated with Energy Poverty } \\
\text { in Ecuador (2014) }\end{array}$} \\
\hline & \multicolumn{2}{|c|}{$\begin{array}{l}10 \% \text { indicator } \\
\text { (Boardman) }\end{array}$} & \multicolumn{2}{|c|}{$\begin{array}{l}\text { Hidden Energetic } \\
\text { Poverty }\end{array}$} & \multicolumn{2}{|c|}{$\begin{array}{l}\text { Disproportionate } \\
\text { Energy Expenditure }\end{array}$} & \multicolumn{2}{|c|}{$\begin{array}{l}\text { Delayed Payment of } \\
\text { Electricity Bills }\end{array}$} \\
\hline & \multicolumn{2}{|c|}{$\begin{array}{l}\text { Number of } \\
\text { Households by Area }\end{array}$} & \multicolumn{2}{|c|}{$\begin{array}{l}\text { Number of } \\
\text { Households by Area }\end{array}$} & \multicolumn{2}{|c|}{$\begin{array}{l}\text { Number of } \\
\text { Households by Area }\end{array}$} & \multicolumn{2}{|c|}{$\begin{array}{l}\text { Number of } \\
\text { Households by Area }\end{array}$} \\
\hline Sierra & 144,056 & $7.50 \%$ & 225,118 & $11.40 \%$ & 409,310 & $21.30 \%$ & 66,079 & $3.40 \%$ \\
\hline Urban & 63,370 & $5.20 \%$ & 93,004 & $7.30 \%$ & 209,163 & $17.10 \%$ & 21,575 & $1.70 \%$ \\
\hline Rural & 80,686 & $11.60 \%$ & 132,113 & $18.80 \%$ & 200,148 & $28.70 \%$ & 44,504 & $6.60 \%$ \\
\hline Coast & 166,505 & $8.30 \%$ & 404,445 & $19.60 \%$ & 513,398 & $25.50 \%$ & 69,194 & $3.80 \%$ \\
\hline Urban & 120,799 & $7.90 \%$ & 248,893 & $15.80 \%$ & 387,639 & $25.30 \%$ & 49,380 & $3.40 \%$ \\
\hline Rural & 45,705 & $9.40 \%$ & 155,552 & $31.80 \%$ & 125,759 & $26.00 \%$ & 19,814 & $5.60 \%$ \\
\hline Amazon & 18,938 & $9.90 \%$ & 41,673 & $21.60 \%$ & 45,794 & $24.00 \%$ & 9,146 & $5.30 \%$ \\
\hline Urban & 3918 & $5.30 \%$ & 12,713 & $17.00 \%$ & 12,031 & $16.30 \%$ & 2,237 & $3.00 \%$ \\
\hline Rural & 15,020 & $12.90 \%$ & 28,960 & $24.60 \%$ & 33,763 & $29.00 \%$ & 6,909 & $7.00 \%$ \\
\hline Galápagos & 140 & $1.70 \%$ & 751 & $9.00 \%$ & 508 & $6.20 \%$ & 38 & $0.40 \%$ \\
\hline Urban & 89 & $1.80 \%$ & 472 & $9.50 \%$ & 356 & $7.30 \%$ & 13 & $0.20 \%$ \\
\hline Rural & 51 & $1.50 \%$ & 279 & $8.30 \%$ & 152 & $4.60 \%$ & 25 & $0.70 \%$ \\
\hline
\end{tabular}

Source Living Conditions Survey-Sixth Round, November 2013-October 2014 (INEC) Prepared by the authors. Bold data refers to the total in each province.

When analysing only by region, the results present fundamentally different realities that correspond to different manifestations of energy poverty; the Coast is the one with the highest percentage of energy poverty in the indicator of disproportionate energy expenditure $(25.5 \%)$. While in the indicators: hidden energy poverty (21.6\%), delays in the payment of receipts $(5.3 \%)$ and Boardman $(9.9 \%)$ identify the Amazon with a higher percentage of energy poverty. 
The provinces that experienced the highest incidence of energy poverty according to indicators: Boardman, hidden energy poverty and disproportionate energy expenditures were Chimborazo, Bolívar, Loja, Esmeraldas, Santa Elena, Manabí, Los Ríos, Morona Santiago, Orellana, when analysed with each of the regions. Regarding the provinces that presented more payment delays, Azuay, Chimborazo, Cotopaxi, Esmeraldas, Los Ríos, Morona Santiago, Napo, Orellana, Pastaza, Zamora Chinchipe. All these provincials have a high incidence of energy poverty, as the high coefficients than the national average estimated in each indicator, suggest.

Results above emphasise the need to consider local-territorial conditions for the measurement and interpretation of the results. An example of this is that in many cases, cultural conventions are determinants in energy consumption, a factor that is not present in the measurement of the indicators applied.

The analysis by socio-demographic conditions of the household confirms specific patterns of vulnerability to energy poverty. Three categories of households stand out: the unipersonal older adults, the bi-parental older adults without children, single-parent and bi-parental with two and more children, this when analysing the indicators: Boardman's rule, hidden energy poverty and disproportionate energy expenditures. When analysing electricity payment delays, two categories appear, single-parent and two-parent with two or more dependent unmarried children.

On the other hand, if analysed by income level, it can be seen in Table 6 that households classified between the 1st and 40th percentile experienced in greater proportion energy poverty in the four indicators. In this regard, a question arises as to how far households in the highest income percentiles are in energy poverty.

Table 6. Percentage of households experiencing conditions associated with energy poverty in Ecuador (2014) by percentile rank.

\begin{tabular}{ccccc}
\hline $\begin{array}{c}\text { Rango de } \\
\text { Percentile }\end{array}$ & $\begin{array}{c}\mathbf{1 0} \text { \% Indicator } \\
\text { (Boardman's Rule) }\end{array}$ & $\begin{array}{c}\text { Hidden Energetic } \\
\text { Poverty }\end{array}$ & $\begin{array}{c}\text { Disproportionate } \\
\text { Energy } \\
\text { Expenditure }\end{array}$ & $\begin{array}{c}\text { Delayed Payment } \\
\text { of Electricity Bills }\end{array}$ \\
\hline $\begin{array}{c}\text { 1st to 20th } \\
\text { percentile income }\end{array}$ & $36.40 \%$ & $29.10 \%$ & $70.70 \%$ & $4.80 \%$ \\
\hline $\begin{array}{c}\text { 21st to 40th } \\
\text { percentile income }\end{array}$ & $3.30 \%$ & $23.10 \%$ & $24.90 \%$ & $3.60 \%$ \\
\hline $\begin{array}{c}\text { 41st to 60th } \\
\text { percentile income }\end{array}$ & $0.80 \%$ & $14.30 \%$ & $15.20 \%$ & $3.40 \%$ \\
\hline $\begin{array}{c}\text { 61st to 80th } \\
\text { percentile income }\end{array}$ & $0.10 \%$ & $9.20 \%$ & $5.70 \%$ & $2.30 \%$ \\
\hline $\begin{array}{c}81 \text { st to 100th } \\
\text { percentile income }\end{array}$ & $0 \%$ & $3.80 \%$ & $2.10 \%$ & $3.40 \%$ \\
\hline
\end{tabular}

Source Living Conditions Survey-Sixth Round, November 2013-October 2014 (INEC) Prepared by the authors.

The result shows that each of the indicators proposed by the EPOV measure different conditions associated with energy poverty. So why not build an index that adds to these indicators, which allows a joint analysis of the incidence.

\subsection{Steps in the Calculation of MEPI.}

Each household is classified as poor (or no-poor) in energy, depending on whether or not the built indicators rate them: Boardman's rule $(10 \%)$, delays in the payment of electricity bills, disproportionate expenses, and hidden energy poverty (selected indicators considering the principles of information availability, accuracy and parsimony) and then add them to a national measurement of multidimensional energy poverty. 
In the case that it is required to build the four indicators for previous years, it is relevant to mention that, as of 2004, the National Institute of Statistics and Census of Ecuador, made updates to the sources of information collection of the Living Conditions Surveys. Also, in 2000, Ecuador replaced the official currency (the 'sucre') to the US dollar. Therefore, not all indicators can be recalculated.

A value is assigned to each household when it has or has not experienced any of the conditions associated with energy poverty according to each of the four indicators of the index (1 when it experiences conditions associated with energy poverty and 0 when it does not). The maximum score is one, and each indicator receives the same weighting; therefore, the maximum score on each indicator is $4^{1 / 4}$ that is, each indicator weights 0.25 , considering that each of the indicators has some influence in the final index.

The thresholds of the indicators used are those proposed by the EPOV (2018) in disproportionate expenditures twice the median in energy expenditure, in hidden energy poverty half of the national median of energy expenditure, and in delays one month and more [11]. In total, $10 \%$ of the disposable income suggested by Boardman [2] is the indicator used related to the income variable.

The scores for each household are added to identify households in multidimensional energy poverty. For the distinction between energy-poor and non-energy poor, a value higher than 0.25 is used as a cut-off point. If the result obtained is higher than 0.25 , the household is in conditions of multidimensional energy poverty. Households with 0.25 conditions associated with energy poverty are vulnerable or at risk of falling into multidimensional energy poverty.

The missing values in each of the estimated indicators are considered as an ignored response; therefore, not knowing the situation of that household, it is not considered as a condition associated with energy poverty. In aggregate, the base presents $1.8 \%$ of cases lost, that is, the household without information cannot classify as in multidimensional energy poverty, so it is not necessary to perform bias analysis of missing values (just when this missing data exceed $15 \%$ ).

The number of conditions calculated in this paper is 2,3 and 4 , with $\mathrm{k}=4$ number of indicators, all of them showed in Table 7.

The multidimensional energy poverty index is a complement to the forms of measurements of this phenomenon. The measurement for the Ecuadorian case year 2014 implied the construction of the variables required for the estimation of selected indicators using of Living Conditions Survey, even though this survey was not designed for this purpose. Therefore, it is essential to mention the index is subject to continuous improvement and this first version would be seen as the beginning of an analysis and adjustment process in the construction of the indicators used, as well as the exploration of the feasibility of adding the other indicators proposed by EPOV in this index for the Ecuatorian case.

Table 8 shows the results of the MEPI expressed in terms of households; in 2014,1.3\% of households nationwide are in conditions of multidimensional energy poverty. Similarly, the results of the two components of the MEPI, the EPIR that measures in terms of households shows that $10 \%$ of the households experienced conditions associated with energy poverty and the IEP, expressed in average percentages, shows that at least $1.3 \%$ households would be energy poor.

The consistency of the proposed index was evaluated by performing two types of variations. First, the four indicators were classified into three dimensions, income (one indicator), expenditure (two indicators) and delays in the payment of bills (an indicator), considering the methodology for their measurement, with which the maximum weight assigned to each dimension. It was $3^{1 / 3}$. Second, the cohort threshold was increased to identify poor energy households weighted to 0.33 . With these variations, the result obtained from the MEPI did not change, which suggests it validates the index consistency.

Households located in the Sierra region fall to a higher percentage $(47.0 \%)$ in multidimensional energy poverty (see Table 8), compared to those of the Costa which represents $45.7 \%$ and the Amazon with $8.3 \%$. When analysing by rural-urban area, there is a clear difference between the Sierra and Amazon regions, rural households fall by a more significant percentage (100\%) in multidimensional energy poverty, while urban homes on the coast are $77.8 \%$ (see Table 9). 
Table 7. A hypothetical example of the calculation of the multidimensional energy poverty index.

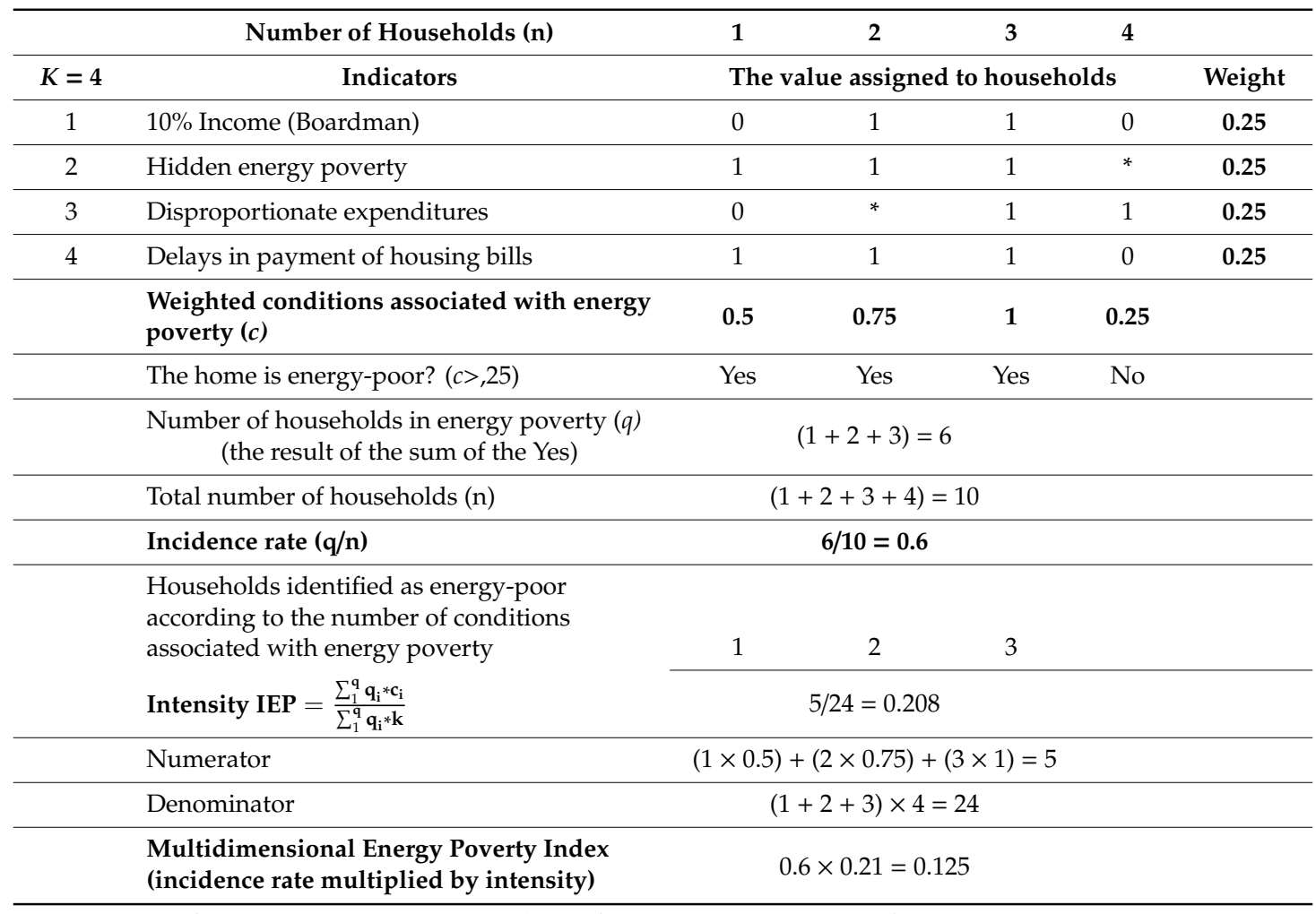

1 = Yes identified in the condition associated with fuel poverty; 0 = No identified in the condition associated with fuel poverty; * ignored answer is not a condition associated with poverty. Source Living Conditions Survey-Sixth Round, November 2013-October 2014 (INEC) Prepared by the authors.

Table 8. Multidimensional energy poverty index for Ecuador in 2014.

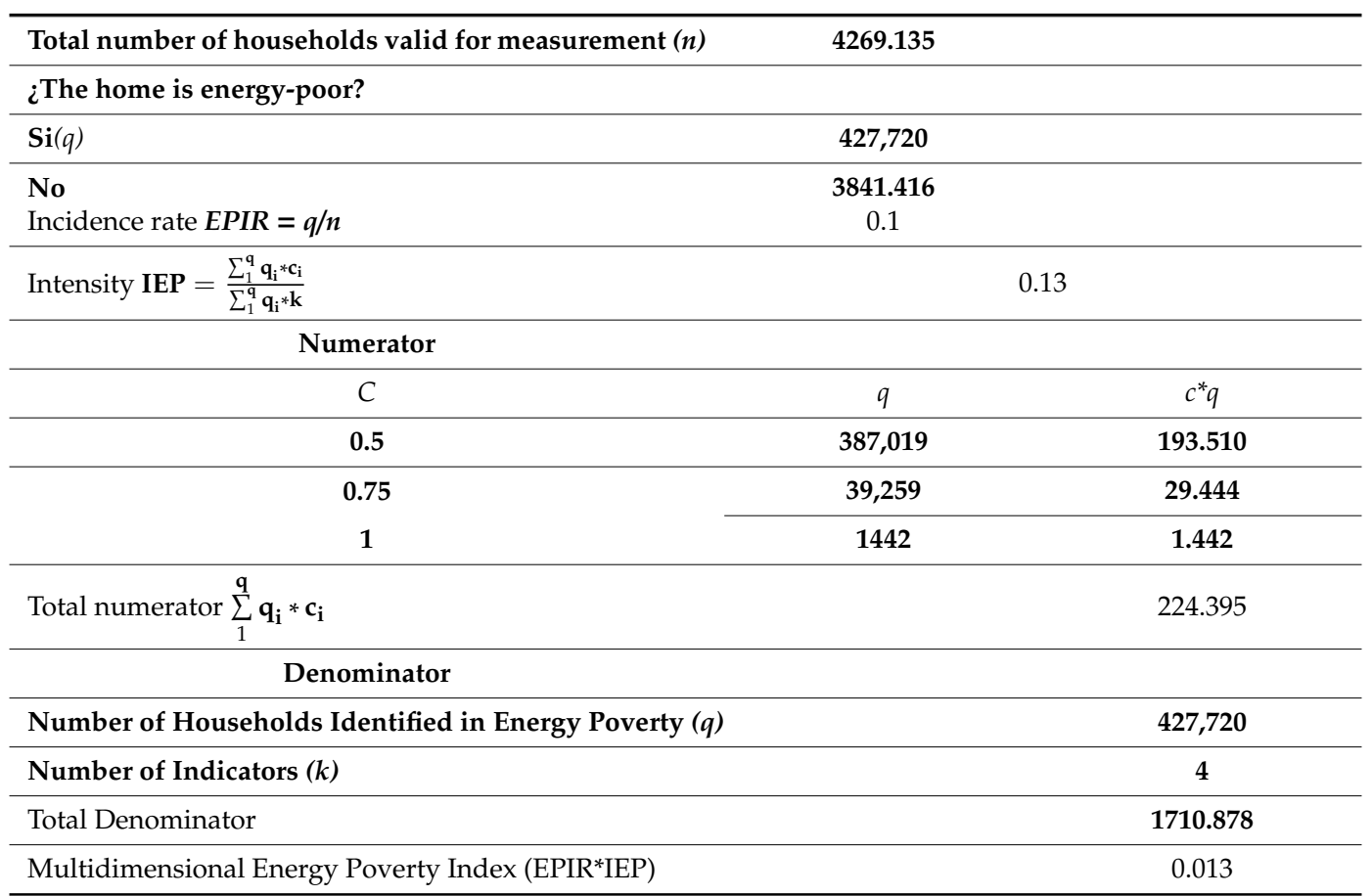

Source Living Conditions Survey-Sixth Round, November 2013-October 2014 (INEC) Prepared by the authors. Bold is used to highlight the relevant numbers in the table. 
Table 9. Multidimensional energy poverty by region and area, 2014.

\begin{tabular}{ccc}
\hline \multirow{2}{*}{ Region and Location } & MPEI & MPEI \\
\cline { 2 - 3 } & $\mathbf{( \# )}$ & $\mathbf{4 7 . 0 0 \%}$ \\
\hline Sierra & $\mathbf{6 7 8}$ & $0 \%$ \\
\hline Urban & - & $100.00 \%$ \\
\hline Rural & 678 & $\mathbf{4 5 . 7 0 \%}$ \\
\hline Coast & $\mathbf{6 3 9}$ & $\mathbf{7 7 . 8 0 \%}$ \\
\hline Urban & 497 & $22.20 \%$ \\
\hline Rural & 142 & $\mathbf{8 . 7 0 \%}$ \\
\hline Amazon & $\mathbf{1 2 5}$ & $100.00 \%$ \\
\hline Urban & - & \\
\hline Rural & 125 & \\
\hline Galápagos & - & \\
\hline Urban & - & \\
\hline Rural & - & \\
\hline Total & $\mathbf{1 4 4 2}$ & \\
\hline
\end{tabular}

Source Living Conditions Survey-Sixth Round, November 2013-October 2014 (INEC) Prepared by the authors. Bold data refers to total in every province

The provinces of Cotopaxi (23.3\%), Los Ríos (26.6\%), Guayas (17.8\%), present a large number of households identified in multidimensional energy poverty, those that should be prioritized in the implementation of public policy.

The results show that single-person households (57.4\%) are more vulnerable to falling into energy poverty, followed by single parents, two parents with one child and more, two parents without children. Additionally, all households identified in multidimensional energy poverty belong to the 1st through 20th percentile of the disposable income distribution.

Table 10 presents the structure of the Multidimensional Energy Poverty Index proposed in this research and the "Multidimensional Energy Poverty Index" proposed by Nussbaumer $[15,16,18]$. The structure in this paper follows the EU Observatory recommendations while the Nussbaumer's is based on data availability issues to define the weights. Differences would be as complementary, and results would support the formulation of public policies.

Table 10. Multidimensional Energy Poverty Indexes.

\begin{tabular}{cccc}
\hline MEPI- Nussbaumer * & \multicolumn{2}{c}{ MEPI- Porposed } \\
\hline Indicators & Weight & Indicators & Weight \\
\hline Modern Cooking fuel & 0.20 & $10 \%$ rule & 0.25 \\
\hline Indoor pollution & 0.20 & $\begin{array}{c}\text { Hidden energy } \\
\text { poverty }\end{array}$ & 0.25 \\
\hline Electricity access & 0.20 & $\begin{array}{c}\text { Disproportionate } \\
\text { expenditures }\end{array}$ & 0.25 \\
\hline Household appliance ownership & 0.13 & $\begin{array}{c}\text { Delays in payment } \\
\text { of housing bills }\end{array}$ & 0.25 \\
\hline Entertainment education appliance ownership & 0.13 & & \\
\hline Telecommunication means. & 0.13 & & \\
\hline Souces, ${ }^{*}$ Nussbaumer et al. 2013, p.2063, Nussbaumer et al. 2011, p.9. Prepared by the Author.
\end{tabular}




\section{Conclusions}

This research seeks evidence of the presence of energy poverty in Ecuador for the year 2014, for this, it applies four indicators, three of which were proposed by the European Union Energy Poverty Observatory (EPOV), and one proposed by Boardman (1991). The results show that energy poverty is present in Ecuadorian households, nationwide. Rural households have experienced greater energy poverty than those located in the urban area.

Specific results indicate that, in Ecuador, energy poverty is a phenomenon present in urban and rural areas. Energy poverty is, in absolute terms, higher in rural than urban areas. It affects thousands of households, some of which are in greater vulnerability as they have lost regular access to electricity supply due to non-payment of bills.

A total of 144,456 households, equivalent to $3.7 \%$ of households nationwide, would be experiencing conditions associated with energy poverty. Domestic energy expenditures for $23.4 \%$ of households were disproportionately high to their income and the national median. $15.8 \%$ of households had low energy costs, and $8 \%$ experienced conditions associated with poverty or are in energy poverty in 2014. Bi-parental, single-parent and single-person households are the most likely to experience this phenomenon. Furthermore, households located between the 1st and 40th percentile have a higher incidence.

It is difficult to estimate an index of energy poverty that can be measured and evaluated not only at the country level, but within each of the provinces, especially when its measurement is subject to the use of a precise definition of the concept of energy poverty that influences the results. This issue raises the need to continue advancing in the development of methodologies that look for evidence of the existence and consequences of energy poverty.

It is necessary to apply a battery of indicators and not only use a single indicator to measure energy poverty, to reduce the risk of generating a distorted image by ignoring unidentified vulnerable social groups.

It is necessary to establish regulatory frameworks for the protection of poor consumers to guarantee access to clean, efficient and modern energy sources at affordable prices, which may involve the incorporation of subsidies.

Of the 427,720 households that experienced conditions associated with energy poverty, the empirical exercise can identify $1.442(1.3 \%)$ as multidimensional energy-poor households. This figure represents the most vulnerable population and should be prioritized in the design and implementation of public policy $[8,23]$.

The implementation of public policies implies:

First, the availability of statistical data to identify households living in energy poverty, through the establishment of a robust system that allows the periodic calculation of indicators and their dissemination by the National Institute of Statistics and Censuses.

Second, to carry out an analysis of the energy consumption of the residential sector in Ecuador, by energy sources, final uses and zoning, which allows the identification of changes in consumption habits.

Third, the regulation of cross-subsidies, a dignity tariff, that allows the identification of vulnerable consumers and the design of different levels of social bonus for energy-poor households.

Fourth, to visualise energy poverty in energy consumption regulations, including specific legal treatment for vulnerable consumers.

With this, a National Strategy against Energy Poverty could be established, based on an open and plural participative process.

The results obtained show the relevance of introducing and strengthening energy poverty as a line of research and as an axis of analysis in development plans in Ecuador. As well as the need to refine or design a new instrument for collecting information that is required to measure energy poverty, which implies a direct link between National Institute of Statistics and Census and the companies that supply the energy services. 
Author Contributions: Q.S.P. has worked in all part of the article (theoretical principles, data base construction, empirical exercise and discussion). T.d.L.P.P. has worked in all part of the article (theoretical principles, data base construction, empirical exercise and discussion) and defining the article logic, and J.T.F. has worked in all part of the article (theoretical principles, data base construction, empirical exercise and discussion).

Funding: This research received no external funding.

Conflicts of Interest: The authors declare no conflict of interest.

\section{References}

1. García, R. Pobreza Energética en América Latina. CEPAL Documento de Proyecto 576. 2014. Available online: https://repositorio.cepal.org/bitstream/handle/11362/36661/1/S2014039_es.pdf (accessed on 2 November 2018).

2. Boardman, B. Fuel Poverty: From Cold Homes to Affordable Warmth; Belhaven Press: London, UK, 1991.

3. Koh, L.; Marchand, R.; Genovese, A.; Brennan, A. Fuel Poverty: Perspectives from the Front Line; The University of Sheffield. Center for Energy Environment and Sustainability: Sheffield, UK, 2012; Available online: https://archive.org/details/povertyastudyto00rowngoog/page/n115 (accessed on 10 December 2018).

4. Meszerics, T. Energy Poverty HandbooK. The Greens/EFA Group of the European Parliament. 2016. Available online: https://www.socialeurope.eu/wp-content/uploads/2017/01/energypovertyhandbook-online. pdf (accessed on 12 November 2018).

5. Osbaldeston, J. Fuel poverty in UK cities. Cities 1984, 1, 366-373. [CrossRef]

6. Lewis, P. Fuel Poverty can be Stopped, Bradford. National Right to fuel Campaign. 1982.

7. United Nations for Development Program-PNUD. Ministerio de Energia Chile. Pobreza Energética: Análisis de Experiencias Internacionales y Aprendizajes Para Chile; Programa de las Naciones Unidas para el Desarrollo: Santiago, Chile, 2018; Available online: https://www.cl.undp.org/content/chile/es/home/library/ environment_energy/pobreza-energetica--analisis-de-experiencias-internacionales-y-a.html (accessed on 10 November 2018).

8. Pye, S.; Dobbins, A. Energy Poverty and Vulnerable Consumers in the Energy Sector across the EU: Analysis of Policies and Measures. Policy Report 2015. Available online: https://ec.europa.eu/energy/sites/ ener/files/documents/INSIGHT_E_Energy\%20Poverty\%20-\%20Main\%20Report_FINAL.pdf (accessed on 4 November 2019).

9. Urquiza, A.; Amigo, C.; Billi, M.; Calvo, R.; Labraña, J.; Oyarzún, T.; Valencia, F. Quality as a hidden dimension of energy poverty in middle-development countries. Literature review and case study from Chile. Energy Build. J. 2019, 204, 109463. Available online: https://www.sciencedirect.com/science/article/abs/pii/ S0378778818319790 (accessed on 1 November 2019). [CrossRef]

10. Thomson, H.; Bouzarovski, S.; Snell, C. Rethinking the measurement of energy poverty in Europe: A critical analysis of indicators and data. Indoor Built Environ. 2017, 26, 879-901. [CrossRef] [PubMed]

11. Tirado, S.; Jiménez, L.; López, J.; Irigoyen, V. Pobreza Energética en España. Hacia un Sistema de Indicadores y una Estrategia de Actuación Estatales; Asociación de Ciencias Ambientales: Madrid, Spain, 2018.

12. Mendoza, J.; Ramos, F.; Ramírez, A. Improving Indicators for Comparing Energy Poverty in the Canary Islands and Spain. Energies 2019, 12, 2135. [CrossRef]

13. Maxim, A.; Mihai, C.; Apostoaie, C.; Popescu, C.; Istrate, C.; Bostan, I. Implications and Measurement of Energy Poverty across the European Union. Sustainability 2016, 8, 483. [CrossRef]

14. Kozulj, R. Contribución de los Servicios Energéticos a los Objetivos de Desarrollo del Milenio y a la Mitigación de la Pobreza en América Latina y El Caribe; CEPAL, GTZ, PNUD: Santiago, Chile, 2009.

15. Nussbaumer, P.; Bazilian, M.; Modi, V. Measuring energy poverty: Focusing on what matters. Renew. Sustain. Energy Rev. 2012, 16, 231-243. [CrossRef]

16. Nussbaumer, P.; Bazilian, M.; Modi, V.; Yumkella, K. Measuring Energy Poverty: Focusing on What Matters. University of Oxford OPHI Working Paper No. 42. 2011. Available online: https://www.ophi.org.uk/wpcontent/uploads/OPHI_WP_42_Measuring_Energy_Poverty1.pdf (accessed on 10 November 2018).

17. Mirza, B.; Szirmai, A. Towards a New Measurement of Energy Poverty: A Cross-Communityanalysis of Rural Pakistan; UNU-MERIT Working Papers; No. 024; UNU-MERIT, Maastricht Economic and Social Research and Training Centre on Innovation and Technology: Maastricht, The Netherlands, 2010.

18. Nussbaumer, P.; Fuso, F.; Onyeji, I.; Howells, M. Global Insights Based on the Multidimensional Energy Poverty Index (MEPI). Sustainability 2013, 5, 2060-2076. [CrossRef] 
19. Fabbri, K. Building and fuel poverty, an index to measure fuel poverty: An Italian case study. Energy 2015, 89, 244-258. [CrossRef]

20. Okushima, S. Gauging energy poverty: A multidimensional approach. Energy 2017, 137, 1159-1166. [CrossRef]

21. Ministerio de Electricidad y Energía Renovable. Balance Energético Nacional 2017 con año Base 2016. Ecuador 2017. Available online: https://bit.ly/2ojh8DE (accessed on 15 December 2018).

22. Ministerio de Electricidad y Energía Renovable; BID. Plan Nacional de Eficiencia Energética 2016-2035 Ecuador 2017. Available online: https://www.celec.gob.ec/hidronacion/images/stories/pdf/planee \% 20version\%20espa\%c3\%b1ol.pdf (accessed on 15 December 2018).

23. Electricity Regulation and Control Agency(Agencia de Regulación y Control de Electricidad). Per Capita Anual Consumption. 2017. Available online: https://www.regulacionelectrica.gob.ec/recaudacion-anual/ (accessed on 5 November 2018).

24. Alkire, S.; Foster, J. Counting and Multidimensional Poverty Measurement; OPHI Working Paper Series; OPHI: Oxford, UK, 2008.

25. Alkire, S.; Foster, J.E.; Suman, S.; Santos, M.E.; Roche, J.M.; Ballon, P.; En, O.P. Initiative, Multidimensional Poverty Measurement and Analysis; Oxford University Press: Oxford, UK, 2015.

26. Alkire, S.; Ballon, P. Undestanding Association across Deprivation Indicators in Multidimensional Poverty; Obtenido de OPHI, Universidad de Oxford: Oxford, UK, 2012.

27. Instituto Nacional de Estadística y Censos; LCS. Formulario de la Encuesta de Condiciones de Vida. Sexta Ronda Noviembre 2013-Octubre 2014 y Quinta Ronda: Noviembre 2005-Octubre 2006. 2014. Available online: http://www.ecuadorencifras.gob.ec/banco-de-informacion/ (accessed on 5 December 2018).

28. Instituto Nacional de Estadística y Censos; LCS. Bases de la Encuesta de Condiciones de Vida. Sexta Ronda Noviembre 2013-Octubre 2014. Available online: http://www.ecuadorencifras.gob.ec/banco-de-informacion/ (accessed on 15 May 2017).

29. Instituto Nacional de Estadística y Censos. Metodología de Construcción del Agregado del Consumo y Estimación de Línea de Pobreza en el Ecuador. Revista de Estadística y Medodologías Volume I, Marzo 2015. Available online: https://www.ecuadorencifras.gob.ec//documentos/web-inec/Bibliotecas/Revista_ Estadistica/Revista_de_Estadistica_y_Metodologias-Tomo-I.pdf (accessed on 15 May 2017).

30. Instituto Nacional de Estadística y Censos. Aspectos Metodológicos Sobre la Medición de la Pobreza Por Ingresos en el Ecuador. Revista de Estadísticas y Metodologías. Volumen II, November 2016. Available online: http://www.ecuadorencifras.gob.ec/revista-de-estadistica-y-metodologias/ (accessed on 15 May 2017).

31. Instituto Nacional de Estadística y Censos. (2013-2014) Metodología de la Encuesta de Condiciones de Vida ECV. Abril 2015. Available online: http://www.ecuadorencifras.gob.ec/documentos/web-inec/ECV/ECV_ 2015/documentos/Metodologia/DocumentoMetodologicoECV6R.pdf (accessed on 16 May 2017).

32. Feres, J.; Mancero, X.; Enfoques Para la Medición de la Pobreza. Breve Revisión de la Literatura: División de Estadística y Proyecciones Económicas CEPAL. Serie 4 Estudios Estadísticos y Prospectivas. 2001. Available online: https:/dds.CEPAL.org/infancia/guia-para-estimar-la-pobreza-infantil/bibliografia/ capitulo-I/Feres\%20Juan\%20Carlos\%20y\%20Xavier\%20Mancero\%20(2001a)\%20Enfoques\%20para\%20la\% 20medicion\%20de\%20la\%20pobreza.pdf (accessed on 10 September 2017).

33. Organización Internacional del Trabajo. Informe II “Estadísticas de ingresos y gastos" Decimiséptima Conferencia Internacional de Estadística del Trabajo, Ginebra 2003. Available online: http://www.ilo.org/ wcmsp5/groups/public/---dgreports/---stat/documents/meetingdocument/wcms_087590.pdf (accessed on 2 August 2017).

34. The Camberra Group. Expert Group on Household Income Statistics. Final Report and Recommendations. Ottawa 2001. Available online: http://www.lisdatacenter.org/wp-content/uploads/canberra_report.pdf (accessed on 2 August 2017).

35. Empresa Eléctrica Quito. Rendición de Cuentas años 2014. Ecuador 2014. Available online: https: //www.eeq.com.ec:8443/nosotros/rendicion-de-cuentas (accessed on 20 December 2018). 
36. Asamblea Nacional del Ecuador. Ley Orgánica del Servicio Publico en Energía Eléctrica. 2015; Registro Oficial Suplemento 401 de 21 de Noviembre. Available online: https:/www.iner.gob.ec/wp-content/uploads/ downloads/2015/05/Reglamento.pdf (accessed on 26 December 2018).

37. Asamblea Nacional del Ecuador. Reglamento a la Ley Orgánica del Servicio Publico en Energía Eléctrica. 2015; Registro Oficial Suplemento 418 de 16 de Enero. Available online: https://www.iner.gob.ec/wp-content/ uploads/downloads/2015/05/LOSPEE.pdf (accessed on 18 December 2018).

(C) 2019 by the authors. Licensee MDPI, Basel, Switzerland. This article is an open access article distributed under the terms and conditions of the Creative Commons Attribution (CC BY) license (http://creativecommons.org/licenses/by/4.0/). 